\title{
MAJOR STAGES OF READING SKILLS DEVELOPMENT
}

\author{
AUTHORS' DATA: \\ Astghik Grigoryan, PhD in Education, Associated professor \\ Chair of Speech and Rehabilitative Therapy, ASPU \\ Lecturer \\ Contacts: asokg@mail.ru
}

\begin{abstract}
The article introduces major stages and characteristic features of the entire process of reading. The professional literature data illustrate that the reading process is closely linked to the development of verbal communication. Good reading skills at both elementary and middle schools are a guarantee of high academic achievement, and in the heavy flow of information they are a reliable means of orientation, which the learner deals with. A mastery of good reading skills is the path to early-aged learner's further education as well as the most essential means of communication and information transmission in society.
\end{abstract}

Keywords: reading skills, psychophysiological process, visual perception, sound-symbol relationship, developmental deviations, abstract thinking, expressiveness.

\section{INTRODUCTION}

The studies of native and foreign professional literature show that the process of reading and difficulties, which arise throughout the process, are perpetually in the spotlight of specialists. These issues have been included in the scientific works of psychologists, psycho-physiologists, special educators, and speech therapists (Lalaeva \& Benediktova, 2001).

The intersystem approach should be applied for the development of reading skills, which are improved as a result of long-term and targeted learning. Interest in reading starts to grow when the student is perfectly capable of conscious reading and has an educative and cognitive motivation. Reading is a complicated psychophysiological process, which incorporates visual, oral motor and speech auditory analyzers and, as Badian (1988) noted, "is based on complex 
mechanisms of interaction between a number of analyzers and two signaling systems."(Badian, 1988).

Only complete mental and physiological training can be the basis for a successful school education and will allow to master the complex tasks such as arithmetic, writing, and reading. In the early stages of learning, some children have difficulties with reading and writing. Often parents and teachers view and describe it as laziness, stubbornness, and force the child to read and write extra time, which leads to fatigue and frustration. Of course, this is not the best way to remedy the situation, but on the contrary it causes indifference, mistrust and serious learning difficulties. If one tries to look closely, it becomes obvious that these children find it relatively difficult to learn to read and write in their mother tongue than math, which seems to require more attention and skills. What is the problem about, if the child is not mentally retarded, there are no other problems but he/she is unable to cope with the reading process?

Unfortunately, the disruption of the reading process often occurs at the end of the first grade, which leaves parents in a state of confusion. And only in the second or third year of schooling teachers and parents notice that it is not the result of poor learning, but a much more serious issue for the specialist to deal with (Grigoryan, 2014; Grigoryan, 2016).

\section{LITERATURE REVIEW}

Reading is the complex cognitive process of decoding symbols to derive meaning. It is a form of language processing. Success in this process is measured as reading comprehension. Reading is a means for language acquisition, communication, and sharing information and ideas (Ahissar, 2007).

According to Elkonin (2010) the reading is a complex process, which is structured into three major stages:

1. Word Identification. To read means to see letters, recognize and understand a word or words that are comprised of corresponding, already familiar letters. Not only our sight, but also our memory, imagination, and mental abilities play a key role in recognition of letters as symbolic signs of a word. In addition to spelling out words, one should be able to guess the whole word by recognizing a letter or two. 
2. Comprehension of the reading material. Every word that we read must have its interpretation in our consciousness; in some cases, it may appear as a familiar subject or phenomenon, in other cases as a repetition of the perceived word.

3. Assessment. An early-aged schoolchild doesn't always have a full understanding of the contents of reading material. Initially, the goal is to learn to read, that is, to master the sound system of words comprised of letters. As soon as the young learner has managed to overcome this stage, another motivation comes into view: to clarify the meaning of words in the text they read. Parallel to the development of reading skills, motivations become more complicated, and the student pursues his or her goal of acquiring more information by reading, assessing the main idea, providing explanations to events and phenomena, and having an occasional critical attitude (Soboleva, 2014).

The reading process is closely linked to the development of verbal communication. The expressiveness of reading is cultivated and developed through verbal communication. Intelligible verbal language gives an opportunity to convey the contents of the text fluently and beautifully. A junior schoolchild's reading comprehension differs from an adult's by a number of qualities:

- Lack of full comprehension of the text

- Slowdown in generalization process

- Lack of practical skills

- A marked directness and emotional excitement

- Difficulties in reproduction of speech sounds

In addition to the above, it is important to take into account the peculiarities of an earlyaged schoolchild's cognitive activities. It is very well known that logical thinking is not yet developed at this age; it is of a visual nature and requires the basics of practical activity. The child's mentality gradually acquires visionary and ultimately logical abstract thinking. These gradual stages of a junior schoolchild's cognitive development have their impact on standards of achievement in education (Grigoryan, 2014; Grigoryan, 2016).

The role of adults in shaping children's literacy is crucial, as they are those important persons that surround children with books, read, and introduce them to fiction. If children grow up in an environment where they read and write, they gain a lot of knowledge years before meeting their first teacher. They learn by their own initiative and power, show an amazing ability to be proficient in language, discover the meaning of linguistic structures for themselves, learn to apply 
it skillfully, gradually increasing their level of proficiency. This is a hidden advantage for such children, and allows them to enter the learning phase with a sense of urgency and excitement. But if these children gain early literacy experience at home, unfortunately, many are devoid of it for some reason (Soboleva, 2014). Therefore, preschool teachers and elementary school teachers should prepare children for writing and reading. Specialists call this process emerging or preliteracy. It includes everything that literacy children discover about themselves and what adults teach them (Lyytinen, Erskine, Kujala, Ojanen \& Richardson, 2009).

The formative or pre-literacy stage in a child's experience begins when the child first sees the book and wonders how people are using it, and ends when the child is able to read the words themselves (Heim, Wehnelt, Grande, Huber et al., 2013).

It is early formal and non-formal learning that children receive from preschool and elementary school teachers whose main responsibility is to make sure all children understand what reading and writing are and what they serve to maximize reading proficiency.

Because print is the language they speak, children need to understand the language of print and consciously embrace both their spoken language and the features of the print language.

It is proven that people who speak their native language acquire their spoken language skills before going to school. The ability to understand and use language in order to become a reader is essential, but not sufficient. When children learn to read, they need to have a language understanding (Wandell, Rauschecker \& Yeatman, 2012).

Since print is a spoken language, beginner readers need to understand that their language is real, not just a noise that accompanies thoughts and actions, but something that can be formulated and written into sentences. They need to realize that sentences are made up of words, and the words spoken are composed of syllables and smaller units called sounds. Students should also gain some knowledge of the printed words, to know what the face of the book is, that the printed word is not the pictures, but the signs that "speak", and that the word is presented at the bottom of the page, and from left to right, as well as a number of other important things (Lalaeva \& Benediktova, 2001). Language skills include various components: word, sounds, syntax rules (Wandell, Rauschecker \& Yeatman, 2012).

The social use of language is largely unrelated to literacy, but it is important for children to know the certain rules of social behavior when engaging in discussions that help them understand the text and express their thoughts verbally. For example, children should learn to 
speak in turn, to allow the speaker to finish the thought, not to deviate from the topic, to agree or to parable. At the same time, it is very important for children to know the meaning of word. If the child doesn't know the meaning of a word and is not familiar with the word he/she would have difficulty learning how to read that word. Instead of focusing on each printed word, such children can slide their eyes around the whole line or look at only one letter or confuse written words with pronounced syllables. Printed word recognition is an important skill that consists of two parts. One is recognizing words at once, as you know your friend's face. This is called general recognition of words as soon as the words are recognized (Wandell, Rauschecker \& Yeatman, 2012).

\section{SPEECH THERAPY TASKS WITH CHILDREN}

In addition to the word level, there are other levels of speech that beginner readers should be aware of. These are tanks, initials, rhymes, endings and sounds. The syllables are "pulse" of the language (Elkonin, 2010). These are the rhythmic accents that are heard in the words that give rise to the single, double, plural, and multi-word words. The initials or beginning of a word are the first consonant or vowel of the word, and the rhyme or ending is the last vowel, plus any consonant followed by it.

From the point of view of phonetic awareness, there are a number of tasks that are recommended to perform with students:

- to repeat word syllables with clapping,

- to find single ending words,

- to separate single syllable words into sounds,

- to remove one sound from single syllable words,

- to add one sound from single syllable words,

- to replace one sound with single syllable words to get a new word.

The experts of the field note that children who know that words can be divided into sounds and can perform different actions with sounds will find it easier to perform letter-to-word matching when they start reading than those children who are not familiar with sound functions. That is to say, different works of sounds can improve children's reading skills (Agarkova, 2015).

It should be noted that alphabet knowledge is an important component of a child's emerging literacy. Some children learn to recognize most letters before going to school, and teachers expect all children to recognize all the letters of the alphabet at the beginning of elementary school. Letters 
of knowledge provide two services, giving children insight into what the child has experienced in communicating with the printed text, and on the other hand helping the child to read easily.

\section{Reading features}

At the same time the ability to read is regarded by contemporary teaching methods as automatic verbalization skills. It is crucially important to understand and admit that good reading skills at both elementary and middle schools are a guarantee of high academic achievement. In the heavy flow of information, it is a reliable means of orientation, which the learner deals with. The reading skills development focuses on four qualitative features: accuracy, fluency, consciousness, and expressiveness.

Accurate reading is classified as a process, which combines faultless reading with comprehension of the reading material.

Fluency is the rate of reading conditioned by word recognition and comprehension. The reading rate is measured in the number of characters read per commonly accepted one minute.

Conscious reading is viewed as the perception of the author's intent and artistic means, as well as personal attitude towards the piece of reading material.

Expressiveness is the reader's conveyance of the essential meaning of what has been read to the audience through their own attitude - voice, stress, appropriate phrasing, etc.

These four aspects of reading development are closely interconnected and correlated (Agarkova, 2015).

Without cooperative sound-symbol relationships, the comprehension of separate units of the text is not feasible. The alteration of the meaning of each unit causes discord between them, which in turn leads to the loss of the internal connection of individual components of the text and loss of the meaning of reading material.

Thus, the combination of these four qualitative features is crucial for helping early-aged schoolchildren build their reading skills.

\section{Reading process Stages}

The learner's reading skills development passes through the following stages: analytical, synthetic and automatic. Let us consider them one by one.

At the analytical stage, the early-aged learner needs a great deal of effort to be able to read: see the letter, recognize it, utter the corresponding sound of each graphic sign, do the same with syllables, and grasp the meaning of what they have read. Syllable-reading is generally regarded 
the initial phase of acquiring literacy and reading skills, which, we should note, is shaped differently for every young learner because all cases are individual.

At the synthetic stage, we can observe the simultaneous function of comprehension and reproduction of a piece of reading material take place. At this stage, the learner can read whole words, but the expressive part of reading is still faulty. It is not enough to read and comprehend separate words in the text; the child should be able to understand the meaning of the entire material.

The automatic phase is characterized firstly by a technically correct reading and, secondly, by the reader's immediate emotional response to their own success, as well as desire to share impressions and declare their position. This stage plays a vital role in the development of reading skills, requiring a number of principles from the teacher trainer:

1. Perform reading activities every day

2. Correct mistakes by giving clarifications and explanations

3. Help develop the ability to read quietly, in whisper and ultimately in mind

4. Texts should be presented to an early-aged learner in manageable chunks

5. The choice of texts should be based on the child's psychological state and stylistic peculiarities of the reading material

Work on accurate and fluent reading is very important at an early age. Reading skills can be improved only when readers fully understand what they are reading. To read correctly means to read without mistakes because the latter are likely to affect reading comprehension.

\section{CONCLUSION}

However, in recent years more and more pupils of elementary grades have had difficulty with reading comprehension, which has a negative effect on their writing skills. Specialists refer to these disorders as dyslexia and dysgraphia, which require early detection and subsequent speech therapy, otherwise the whole educational performance may be adversely affected.

There is a genetic predisposition for dyslexia and dysgraphia, which results in it being observed in several family members, even generations (Grigoryan, 2016). Dyslexia is a cause of systemic disorder of higher mental processes, which encompasses not only verbal but also nonverbal mental processes - spatial perception, visual cognition, visual-motor actions, attention, as well as letter graphic processing (Luria, 1992). To understand the mechanism of dyslexia correctly, one must remember that people possess three forms of hearing: semiological, musical, and verbal. 
In the case of speech hearing impairment, it is difficult to perceive the sounds close to the sound, the speech perception (Grigoryan, 2016). Of course, a child who does not clearly understand the word addressed to him does not differentiate the sounds as he/she can read correctly. The problem is that the child has to grasp a particular sound in a large flow of speech, combine it with a graphic image (letter), and correctly spell. That is why the reading instruction becomes a difficult pedagogical problem in the case of hearing impairment. In addition to phonetic hearing, a person possesses the ability to perceive the letter in a special way. It is clear to see the surrounding midpoint, yet does not mean to fully imagine the graphic image of the sound - the letter (Ahissar, 20017).

Studies have made it possible to identify a number of errors that early-aged schoolchildren tend to make.

1. Sound-symbol deviations, which are as follows:

$\checkmark$ Omission of letters, syllables, even phrases

$\checkmark$ Relocation of letters, syllables and words

$\checkmark$ Addition of new units, or replacement of one unit with another

Such errors can be caused by both visual and articulation deviations.

2. Another frequently committed error is repetition of words, syllables and sentences. As a rule, repetition is caused by the fact that the reader tries to set down a new piece of reading material in his or her own memory. Keep in mind that at the above-mentioned analytical stage such repetitions are regular and expected, and should not be regarded as wrong unless they hinder progress towards further stages.

3. Literally correct speech deviations. This sort of reading errors include wrong pronunciation, wrong accent and intonation, as well as "orthographic reading." The latter is typical for the initial stage and means reading the way words are spelt out, not as they sound. The sooner the student will be able to combine and coordinate all the stages of the reading process, the faster "orthographic reading" phase will be over.

The discovery of a predisposition to students' reading difficulty allows them to perform specific tasks of studying the verbal and non-verbal mental processes underlying the reading process. According Lalaeva (2001) the late detection of reading difficulties brings significant difficulties in learning processes and requires long-lasting corrective intervention (Lalaeva, Benediktova, 2001). Earlier detection of a particular difficulty positively results in ongoing 
pedagogical work and, of course, allows for the prevention of secondary emotional and behavioral disorders (Grigoryan, 2016).

Thus, a mastery of good reading skills is the path to early-aged learner's decent education afterwards. It is considered to be the most essential means of communication and information transmission in society.

Each student goes through all of the above-mentioned stages of reading development in their own way. The reading skills development entails a highly coordinated and specific type of pedagogical work.

\section{REFERENCE LIST}

1. Agarkova, N. G. (2015) Azbuka. Obucheniye gramote i chteniyu (Learning reading and writing). 1 class. Metodicheskoe posobie, N.G. Agarkova, Yu. A. Agarkov - M.: Akademkniga/Uchebnik. - 208 s.

2. Ahissar, M. (2007) "Dyslexia and the anchoring-deficit hypothesis". Trends Cogn. Sci. (Regul. Ed.). 11 (11): 458-65. doi:10.1016/j.tics.2007.08.015

3. Badian, N. A., (1988) The prediction of good and poor reading before Kindergarten entry: A nine-year follow-up, Journal of Learning Disabilities, Vol. 21. 98-123.

4. Elkonin, D. B. (2010) Eksperementalniy analiz nachalnogo etapa obucheniya chteniyu (Experimental analysis of the initial stage of reading instruction), Voprosi psikhologii uchebnoy deyatelnosti mladshikh shkolnikov - M.: Izdatelstvo Prosvesheniya - s. 7-50.

5. Grigoryan A. G. (2014) Disleksiayi nakhatramadrvatsutyan bacahaytman hetazotutyan ardyunqnery (Results of a dyslexia predisposition study), Hatuk krtutyan himnakhndirneri gitakan handes N1, Yerevan, 58-65

6. Grigoryan A. G. (2016) Disleksiayi arajacman patjarnery ev kankhargelman ughinery (Causes and Prevention of Dyslexia), Mankavarzhakan mitq, Zangak, Yerevan, 89-93

7. Heim, S., Wehnelt, A., Grande, M., Huber, W., Amunts, K. (2013) Effects of lexicality and word frequency on brain activation in dyslexic readers". Brain and Language.

8. Lalaeva, R. I., Benediktova L. V. (2001) Diagnostika i korrekciya narusheniy chteniya iI pisma u mladshikh shkolnikov (Yound schoolers writing problems' diagnosis and correction). - SPb.: Izdatelstvo "SOYUZ" - s. 3-88. 
9. Luria, A. R. (1992) Visshie korkovie funkcii cheloveka i ikh narusheniya pri lokalnikh porajeniyakh mozga (Higher cortical functions of a person and their disorders in local brain lesions). - M: Prosveshenie. - s. 432.

10. Lyytinen, H., Erskine. J., Kujala, J., Ojanen, E., Richardson, U. (2009). "In search of a science-based application: a learning tool for reading acquisition". Scandinavian Journal of Psychology. 50 (6), 668-75.

11. Soboleva, A. E. (2014) Kak podgotovit rebenka k obucheniyu gramote (How to prepare your child for literacy), A.E. Soboleva. - M.: Detstvo-Press. - 112 s.

12. Wandell, B. A, Rauschecker, A.M., Yeatman, J.D. (2012). "Learning to see words". Annual Review of Psychology, Vol. 63, 31-53. 